REVIEW PAPER

\title{
THE ROLE OF BIOELEMENTS IN IMPROVING THE QUALITY OF LIFE OF PATIENTS SUFFERING FORM THE PREMENSTRUAL SYNDROME (PMS)
}

\author{
Marta Makara-Studzińska ${ }^{1}$, \\ Justyna Morylowska-Topolska ${ }^{2}$, Małgorzata Sztanke ${ }^{3}$, \\ Kazimierz Pasternak ${ }^{3}$ \\ ${ }^{1}$ Individual Department of Mental Health \\ ${ }^{2}$ Department of Psychiatry \\ ${ }^{3}$ Chair and Department of Medical Chemistry \\ Medical University of Lublin
}

\begin{abstract}
The Premenstrual Syndrome (PMS) is described as a cyclical disorder related to the hormonal changes during a menstrual cycle, which affects the emotional and physical health of many women during their reproductive period of life. The PMS can obviously change the quality of life. The syndrome is characterized by a complex group of symptoms, such as depression, irritability, mood swings, anxiety, abdominal discomfort. These signs occur during the luteal phase of a menstrual cycle and disappear after the onset of menses.

Some studies suggest that a variety of nutrients may play an important role in the mood swings which occur cyclically during the course of the premenstrual syndrome and that some can have a beneficial impact, especially on the estrous phase of a menstrual cycle.

The aim of the paper is to review the results of some studies concerning the role of bioelements in patients with the PMS.

Concentrations of magnesium, zinc, selenium and manganese are the highest during menses and the lowest in the ovulatory phase.
\end{abstract}

Marta Makara-Studzińska dr hab. M.D. Individual Department of Mental Health, Medical University of Lublin, Chodzki 15, 20-093 Lublin, Poland, e-mail: mmakara@go2.pl 
Fluctuations of the magnesium concentration during a menstrual cycle and the involvement of this element in many cellular pathways and neuromuscular activities obviously affect the incidence or intensity of the PMS symptoms. However, we lack firm evidence that magnesium supplementation can have a positive effect on alleviating the the PMSrelated ailments.

Some relationship between the PMS and bone demineralization or depressed calcium concentration in blood has been identified. However, further studies are necessary to examine how the calcium concentration in a human body can decrease the intensity of the PMS symptoms.

Key words: premenstrual syndrome (the PMS), bioelements.

\title{
ROLA BIOPIERWIASTKÓW W POPRAWIE JAKOŚCI ŻYCIA PACJENTEK Z ZESPOŁEM NAPIĘCIA PRZEDMIESIĄCZKOWEGO
}

\begin{abstract}
Abstrakt
Zespół napięcia przedmiesiączkowego jest opisywany jako cykliczne zaburzenie związane ze zmianami hormonalnymi w cyklu miesiączkowym, które w istotny sposób wpływa na stan emocjonalny i somatyczny wielu kobiet będących w wieku reprodukcyjnym. Zespół napięcia przedmiesiączkowego może negatywnie wpływać na jakość życia. Na zespół ten składa się grupa objawów, takich jak depresja, drażliwość, wahania nastroju, niepokój, dyskomfort w jamie brzusznej. Objawy te pojawiaja się podczas fazy lutealnej cyklu menstruacyjnego i znikają tuż po pojawieniu się miesiączki.

Opublikowano kilka badań, których wyniki wskazują na to, że różne biopierwiastki moga odgrywać istotną rolę $\mathrm{w}$ cyklicznie pojawiających się $\mathrm{w}$ przebiegu zespołu napięcia przedmiesiączkowego zaburzeniach nastroju, a niektóre z nich moga nawet korzystnie wpływać zwłaszcza na fazę estrogenowa cyklu.

Celem artykułu jest przegląd wyników badań dotyczących znaczenia biopierwiastków $\mathrm{u}$ pacjentek $\mathrm{z}$ zespołem napięcia przedmiesiączkowego.

Okazuje się, że stężenie magnezu, cynku, selenu i manganu jest najwyższe podczas menstruacji, a najniższe podczas owulacji.

Wahania stężenia magnezu $\mathrm{w}$ trakcie cyklu miesiączkowego oraz udział tego pierwiastka w wielu przemianach komórkowych oraz w funkcjonowaniu układu nerwowego i mięśniowego wpływają $\mathrm{z}$ cała pewnościa na pojawienie się oraz nasilenie objawów zespołu napięcia przedmiesiączkowgo. Jednak nie ma do tej pory przekonujących dowodów na to, że suplementacja magnezu może mieć pozytywny wpływ na złagodzenie dolegliwości związanych z omawianym zespołem.

Stwierdzono zależność między zespołem napięcia przedmiesiączkowego a demineralizacją kości i obniżeniem stężenia wapnia we krwi. Konieczne sa jednak dalsze badania dotyczące tego, jak stężenie wapnia w organizmie może wpłynąć na zmniejszenie nasilenia objawów zespołu napięcia przedmiesiączkowego.

Słowa kluczowe: zespół napięcia przedmiesiączkowego, biopierwiastki.
\end{abstract}

\section{INTRODUCTION}

The Premenstrual Syndrome (PMS) is described as a cyclical disorder related to the hormonal changes in the menstrual cycle, which affects the emotional and physical health of many women during their reproductive 
period of life. The syndrome is characterized by a complex group of symptoms that occur during the luteal phase of the menstrual cycle but disappear soon after the onset of menses (THYS-JACOBS 2000).

The symptoms are limited to the luteal phase of the menstrual cycle, abate shortly after the onset of menses, and commonly include depression, irritability, mood swings, bloating, breast tenderness and abdominal discomfort. Women with predominant affective symptoms may also meet the criteria for the premenstrual dysphoric disorder, a more severe form of the PMS associated with significant impairment of normal functions; recent studies estimate that 5 to $8 \%$ of premenopausal women meet the criteria set for the premenstrual dysphoric disorder (BERTONE-JOHNSON et al. 2005).

Because of the number and diversity of the symptoms, many theories and mechanisms have been proposed to explain this syndrome, with an array of therapeutic approaches offered. Most of these approaches have proven disappointing and scientifically unfounded (THYS-JACOBS 2000).

There are some studies that suggest that a variety of bioelements may play an important role in the phase when mood swings and behavioural disturbances of the premenstrual syndrome appear, and some of these micronutrients can even level their cyclic fluctuations during the estrous and menstrual cycles.

The aim of the paper is to review the results of some studies concerning the role of bioelements in patients with the PMS.

There is some firm evidence that the PMS is related to hormonal fluctuations during a menstrual cycle and occurs only in women with ovulatory cycles. The PMS does not occur prepubertally or during a menopause (FERRIN et al. 1993).

The ovarian activity is cyclical and variations in the metabolism of bioelements may accompany hormonal fluctuations during a normal menstrual cycle and may help explain some characteristics of the PMS. Cyclical fluctuations during the estrous cycle have been demonstrated in a few animal investigations. The cyclic hormonal changes can affect a variety of physiological and biochemical processes. It has been reported that oestrogen induces hypercalcemia through the action of the parathyroid gland. Withdrawal of oestrogen is reported to cause a significant loss of bone calcium. It has been observed that an increase in the basic metabolic rate and oxygen consumption during the luteal phase is associated with increased carbohydrate utilization. This elevated metabolism requires magnesium ions and oxidative enzymes, which have been found to increase significantly during the luteal phase. It has also been found that the phosphate concentration falls more rapidly than the calcium rise after administration of the parathyroid hormone. This decline in the phosphate concentration is caused by a strong effect of the parathyroid hormone on the kidney, causing renal phosphate excretion (Dullo, Vedi 2008). PANDYA et al. (1995) have reported that serum inorganic phosphorus levels were higher in the menstrual phase as com- 
pared to the other phases. These ions are regulated by various hormones but predominantly by the sex hormones.

Concentrations of magnesium, zinc, selenium and manganese are the highest during menses and the lowest in the ovulatory phase. There is a rise in ionized magnesium and selenium levels, with a fall in zinc and manganese during the luteal phase. MunEYyIRCI-Delale and NACHARAJU (1999) noted a significant increase in the serum $\mathrm{Ca}^{2+} / \mathrm{Mg}^{2+}$ ratio both in the ovulatory and luteal phases in healthy women.

In thirty-two women with the PMS, supplementation with $360 \mathrm{mg} \mathrm{day}{ }^{-1}$ of magnesium (during the second half of a menstrual cycle) significantly reduced the general PMS symptoms and specially those related to mood changes. It should be noted that the experimental design resulted in the placebo group receiving only two months of supplementation at crossover, whereas the magnesium group received the supplement for four months (FACCHINETTI et al. 1991a). In 20 patients with premenstrual migraine, prophylactic supplementation with magnesium $\left(360 \mathrm{mg} \mathrm{day}^{-1}\right.$ or placebo during the second half of a menstrual cycle) significantly reduced the number of days with a headache (FACCHINETTI et al. 1991b).

Chuong and Dawson (1994) in their trial determined that the level of zinc in blood in patients with the PMS was significantly lower during the luteal phase than during the follicular phase, whereas in the controls zinc values were not significantly different between the follicular and the luteal phases. Copper levels were noted to be higher during the luteal phase in the PMS patients compared with the controls. Because copper competes with zinc for intestinal absorption and serum protein binding sites, the zinc/copper ratio can reflect the availability of zinc in the body. The calculated values of this ratio revealed that it was significantly lower during the luteal phase in treated patients than in the controls.

Thus, fluctuations in the metabolism of bioelements, especially calcium and the calciotropic hormones, have been observed during both the menstrual and estrous cycles, and these cyclical changes may help explain some of the features of the PMS.

Magnesium fluctuates throughout a menstrual cycle and is involved in many cellular pathways and neuromuscular activities which affect the PMS. The clinical evidence on magnesium supplementation, although promising, remains limited. A double blind randomized study examined the effect of magnesium (360 mg day ${ }^{-1}$ ) compared to placebo during two cycles. Magnesium was administered during the luteal phase of a menstrual cycle until the onset of menstrual flow. Although magnesium was found to reduce total symptom scores and the negative group of symptoms, the baseline symptom scores between the treatment groups was significantly different and the expected placebo effect was lacking in this trial. In another study, benefits of magnesium supplementation for the PMS patients were investigated in a double blind crossover trial over four menstrual cycles (THYs-JACOBS 2000). 
Magnesium is an important element that helps to form bones, relaxes muscle spasms, activates cellular enzymes, regulates nerve and muscle function (including the heart) and acid-alkaline balance. It is often referred to as an anti-stress element. Deficiency of magnesium is known to cause many symptoms usually associated with the PMS, such as irritability, depression, confusion and muscle aches. However, determining if a woman is deficient in magnesium can be a challenge.

Many sources of food that are thought to contain magnesium according to old nutrient charts (grains, legumes, vegetables, nuts and seeds) are actually low due to magnesium deficit in soil and its depletion during processing and cooking. Measuring magnesium levels in the blood plasma will often fail to demonstrate low levels, although erythrocyte magnesium levels have been shown to be low in the PMS patients (Rosenstein, Elin 1994). Therefore, woman who want to have a true picture of their magnesium levels should be encouraged to have an erythrocyte magnesium level test done. Oestrogen enhances the utilization of magnesium. However, if oestrogen levels are high, which is often the case in the PMS, and magnesium intake is less then optimal, oestrogen-induced shifts of magnesium can be deleterious, leading to muscle spasms, migraine, and other PMS disorders. In one study, serum levels of magnesium were inversely related to the serum level of oestrogen (SEELIG 1993).

Magnesium supplementation can help to alleviate many measurable parameters of the PMS, including cramps, irritability, fatigue, depression and water retention. Magnesium citrate, gluconate, and lactate are better absorbed than magnesium oxide. Magnesium glycinate is a well absorbable form of magnesium, with minimum laxative effects (WALKER, DE SouzA 1998).

Two investigations have identified a relationship between the PMS and bone loss, further indicating a derangement in calcium metabolism in the PMS as a potential biologic trigger. In 1994, LEE and KANIS (1994) examined the relationship of premenstrual and postmenopausal symptoms with vertebral osteoporosis by means of a retrospective case control questionnaire.

Three calcium trials have demonstrated the efficacy of calcium treatment. Another randomized, double blind crossover trial was conducted to assess the effectiveness of calcium in women with the PMS (THYS-JACOBS et al. 1998).

Continuing Survey of Food Intakes by Individuals (ClevELAND et al. 1996) shows that among menstruating women (ages 12 to 50 years) the mean daily intake of calcium ranged from 607 to $809 \mathrm{mg}$, suggesting that most of the population at risk of the PMS are not receiving the recommended intake levels. Therefore, since most women consume far less than $1.0 \mathrm{mg}$ day $^{-1}$ of calcium from food, they would not exceed the safety limit if they added 1.0-1.2 mg day ${ }^{-1}$ of supplemental calcium to their normal dietary intakes. Calcium, unlike some other supplements tested for the PMS relief efficacy, is safe even to women who may become pregnant. It is also relatively inexpensive, especially in comparison with prescription medications. 
The PMS shares many of the features of depression, anxiety and the dysphoric states. Recent evidence has suggested that the PMS may be associated with some disorder in calcium homeostasis and parathyroid hormone dysregulation. In addition to the abnormalities in calciotropic hormones and the clinical response observed on calcium supplementation in the PMS, a relationship between the PMS and bone loss has been identified, further supporting a derangement in calcium metabolism occurring during the PMS. Clinical illness such as the PMS could be a reflection of an important physiological disruption in calcium regulation, while an adequate treatment of the PMS could help to restore bone mineral homeostasis and reverse the associated neuropsychiatric disturbances (THYS-JACOBS 2000).

\section{REFERENCES}

Bertone-Johnson E., Hankinson S., Bendich A., Johnson S., Willett W., Manson J. 2005. Calcium and vitamin $D$ intake and risk of incident premenstrual syndrome. Arch. Intern. Med., 165: $1246-1252$.

Cleveland L., Goldman J., Borrud L. 1996. Results from USDA's 1994 continuing survey of food intakes by individuals and 1994 diet and health knowledge survey. Agricultural Research Service, U.S. Department of Agriculture, Riverdale.

Chuong C.J., Dawson E.B. 1994. Zinc and copper levels in premenstrual syndrome. Fertil. Steril., 62(2): 313-20.

Dullo P., Vedi N. 2008. Changes in serum calcium, magnesium and inorganic phosphorus levels during different phases of the menstrual cycle. J. Hum. Reprod. Sci., 1(2): 77-80

Facchinetti F., Borella P., Sances G., Fioroni L., Nappi R., Genazzani A. 1991a. Oral magnesium successfully relieves premenstrual mood changes. Obstet. Gynecol., 78: 177-181.

Facchinetti F., Sances G., Borella P., Genazzani A., NapPi G. 1991b. Magnesium prophylaxis of menstrual migraine: effects on intracellular magnesium. Headache, 31: 298-301.

FERRIN M., Jewelewicz R., WARRen M. 1993. The premenstrual syndrome. In: The menstrual cycle. Oxford University Press, pp. 198-204.

LeE S.J., KANIS J.A. 1994. An association between osteoporosis and premenstrual and post-menstrual symptoms. Bone Mineral, 24: 127-134.

Muneyyirci-Delale O., Nacharaju V., Dalloul M., Altura B., Altura B.T. 1999. Serum ionized magnesium and calcium in women after menopause: inverse relation of estrogen with ionized magnesium. Fertil. Steril., 71: 869-872.

Pandya A., Chandwani S., Das T., Pandya T. 1995. Serum calcium, magnesium and inorganic phosphorus levels during various phases of menstrual cycle. Ind. J. Physiol. Pharmacol., 39: 411-414.

Rosenstein D.L., Elin R.J. Hosseini J. M. 1994. Magnesium measures across the menstrual cycle in premenstrual syndrome. Biol. Psych., 35(8): 557-561.

SEELIG M.S. 1993. Interrelationship of magnesium and estrogen in cardiovascular and bone disorders, eclampsia, migraine and premenstrual syndrome. J. Am. Coll. Nutr., 12(4): 442-58.

Thys-Jacobs S. 2000. Micronutrients and the premenstrual syndrome: The case for calcium. J. Am. Coll. Nutr., 19(2): 220-227.

Thys-Jacobs S., Starkey P., Bernstein D. 1998. Premenstrual syndrome study group. Calcium carbonate and the premenstrual syndrome: effect on premenstrual and menstrual symptoms. Am. J. Obstet. Gynecol., 179(2): 444-452.

Walker, A.F.; De SouzA, M.; Vickers M. 1998. Magnesium supplementation alleviates premenstrual symptoms of fluid retention. J. Womens Health., 7(9): 1157-1165. 